\title{
ICEP 2011 (International Conference on Electronics Packaging) 報告
}

\author{
横山 吉典（技術研究組合 BEANS 研究所）
}

\section{1. はじめに}

2011 年 4 月 13 日から 15 日まで, 奈良県新公会堂で ICEP 2011 (The International Conference on Electronics Packaging）が開催された。エレクトロニクス実装学会と IEEE CPMT Society Japan Chapter との共催で，日本で開 催する実装に関する国際会議である。前身である IMC (International Microelectronics Conference, 1980 年開催) から数えて, 本会議が 24 回目となる。メイン会場となる能 楽ホールは, 図 1 に示すように, 日本の伝統芸能の雾囲気 を感じることができる場所であり，国際会議の場所として もふさわしく感じられた。

\section{2. 会議の概要}

本会議では， 5 件の基調講演と 163 件の口頭発表， 32 件 のポスター発表が予定されていた。日本での実装関連の国 際会議ではあるが, 約半数は海外からの発表である。日本 以外の参加国は, 発表件数の多い順に, 台湾 27 件, USA 16 件, マレーシア 11 件, 中国 11 件, 韓国 9 件, ドイツ 7 件 を含め 14 力国である。ところが， 3 月 11 日に発生した東 日本大震災の影響をうけ，残念ながら 2 割程度のキャンセ ルが発生した。このため, キャンセルの時間帯に急遽特別 講演が組み込まれたりした。また，ランチタイムに開催さ れたポスターセッションでは，ポスターの掲示位置を調整 したりなど，運営には様々な工夫がなされていた。最終的 には参加者は 300 名程度とのことであった。

基調講演では，台湾の Industrial Technology Research Institute の Fellow Dr. John H. Lau 氏が 3D-IC/Si などの パッケージに関する歴史および将来展望を含めた動向につ いて講演された。また, Samsung Electronics の Dr. Taejoo Hwang 氏によるモバイル用の 3D 実装の動向に関しての講 演などがなされた。

発表論文数を分野別に分類すると, 図 2 のようになる。 デザインや信頼性に関する発表が最も多く, ついで, イン ターコネクト技術，MEMS の順になった。MEMS では， 金微粒子による低温気密封止，大気中での $\mathrm{Au}-\mathrm{Au}$ 表面活性 化接合（SAB），エレクトロスピニング法を用いたガラスナ ノパーティクルの作成方法などの発表が行われた。この MEMS セッションの中で, BEANS 特集として, 平成 20 年 7 月より開始された経済産業省「異分野融合型次世代デ バイス製造技術開発」プロジェクト(BEANS プロジェクト)

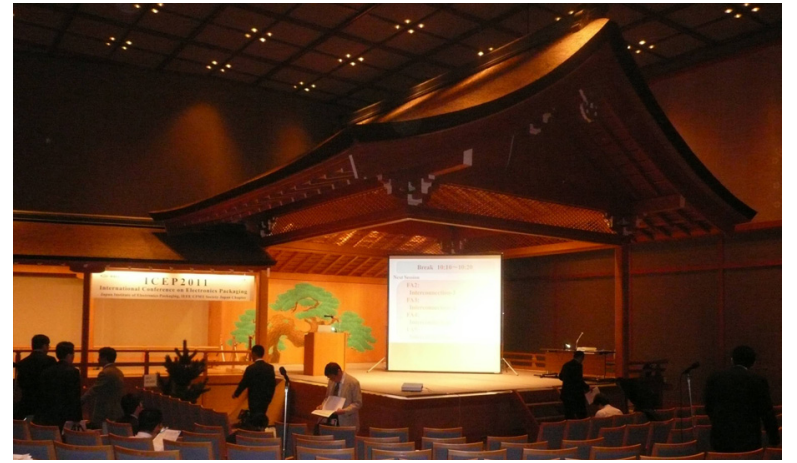

図 1 メイン会場（能楽ホール）

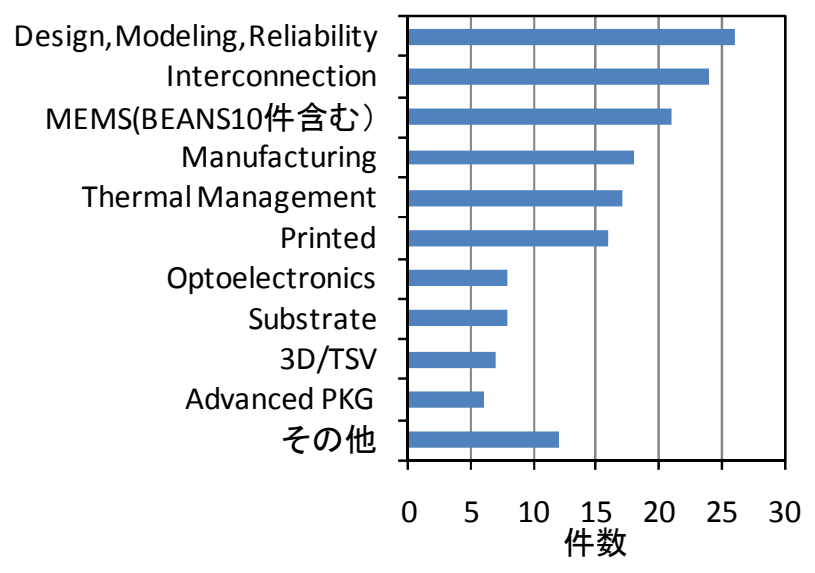

図 2 発表論文数の分野別比較

(平成 21 年 4 月より NEDO 技術開発機構委託）に関する 10 件の成果発表が行われた。また, プリンティング関連で は, TFT 用のインクジェット技術に関する最新の動向に関 する報告や，銀と銅の混合ナノ粒子を用いた低温接合プロ セスの報告などがなされ, 活発な質疑が行われていた。各々 の具体的な発表内容については, CD-ROM 予稿集を参考に していただきたい。

\section{3. おわりに}

本国際会議では，海外の実装技術の最新動向を日本で手 軽に知ることのできる学会である。発表件数も増加してき ており, キャンセルは発生したものの今回は 200 件に到達 した。次回開催は，2012 年 5 月 9 日から 11 日まで, 芝浦 工業大学豊洲キャンパスで開催される予定である。

(平成 23 年 6 月 3 日受付) 